\title{
TEKNIK PEMIJAHAN ALAMI IKAN ARWANA SUPER RED (Scleropages formosus) DI PT. ARWANA, DEPOK, JAWA BARAT
}

\section{Natural Fish Spawning Technique of Super Red Arowana (Scleropages formosus) in PT. Arwana, Depok, West Java}

\author{
Pemuda Arya Pamungkas ${ }^{1}$ dan Prayogo ${ }^{2}$. \\ ${ }^{1}$ Program Studi Budidaya Perairan, Fakultas Perikanan dan Kelautan, Universitas Airlangga, Surabaya \\ ${ }^{2}$ Departemen Manajemen Kesehatan Ikan dan Budidaya Perairan, Fakultas Perikanan dan Kelautan, Universitas \\ Airlangga, Surabaya \\ *pemuda.arya.pamungkas-2012@fpk.unair.ac.id
}

\begin{abstract}
Abstrak
Ikan Arwana super red merupakan ikan yang memiliki warna dan bentuk yang mengagumkan. Ikan jenis ini banyakdicari oleh kolektor ikan hias karena dianggap dapat mendatangkan hoki. Permintaan pasar yang terus menngkat tidak dibarengi dengan meningkatnya produksi ikan dari produsen. Diperlukan adanya informasi tentang pemijahan alami dari ikan arwana super red. Tujuan praktek kerja lapang yang telah dilakukan untuk mengetahui standard operasional yang benar tentang pemijahan alami ikan arwana super red di PT. Arwana, dengan mengetahui standard operasional teknik pemijahan ikan arwana dapat ditemukan juga hambatan yang muncul saat proses pemijahan ikan arwana super red. Kegiatan pemijahan secara alami pada ikan Arwana Super Red meliputi persiapan kolam dengan melakukan pengeringan kolam tanah selama satu minggu. Langkah selanjutnya adalah menanam tanaman sejenis padi. Setelah itu dilakukan pengisian air pada kolam tanah. Seleksi induk untuk memilih induk yang matang gonad kemudian memasukanikan sebanyak 60 ekor per kolam dengan perbandingan jantan betina 1:1 dengan jumlah jantan 30 dan betina 30. Langkah selanjutya dilakukan pemberian pakan berupa katak hidup yang telah disterilkan dengan menggunakan air mengalir. Setelah satu bulan ikan arwana memijah secara alami. Langkah terakhir adalah melakukan pemanenan benih.
\end{abstract}

Kata kunci: Arwana dan Pemijahan Alami

Abstract

Super red arowana fish is a fish that has amazing colors and shapes. This type of fish sought by ornamental fish collectors because they can bring luck. Increasing market demand was not accompanied by increased production of fish from the manufacturer. Information is required about the natural spawning of super red arowana fish. The purpose of the practice work that has been done to determine the correct standard operating on natural spawning super red arowana fish in PT. Arowana, by knowing the operational standards arowana fish hatchery practices can be found also obstacles that arise during the process of super red arowana fish spawning. Event spawning naturally in fish Arowana Super Red includes the preparation of the pool by draining the pond soil for one week. The next step is to plant a type of rice plant. Once that is done filling the water on the ground pool. Parent selection to select the parent mature gonads then put the fish as much as 60 birds per pool with a male female ratio of $1: 1$ to the number of males and females 3030 . Step selanjutya conducted feeding in the form of a live toad that has been sterilized using running water. After one month of arowana fish spawn naturally. The last step is to harvest the seeds.

Keywords: Arowana and Natural Spawning

\section{PENDAHULUAN}

Ikan hias air tawar merupakan salah satu komoditas ekspor yang memiliki nilai ekonomis yang tinggi. Kebiasaan masyarakat memelihara ikan hias sebagai pajangan merupakan suatu peluang yang perlu diperhatikan baik ikan hias air tawar maupun ikan hias air laut. Permintaan terhadap ikan hias terus meningkat sehingga memerlukan ketersediaan dalam jumlah besar, penyediaan dapat dilakukan dengan mengumpulkan hasil tangkapan atau membudidayakannya sendiri. Tujuan utama dalam pemasaran untuk ekspor ikan hias Indonesia meliputi, antara lain negara Jepang, Singapura dan Eropa. Negara 
pengekspor ikan hias yang merupakan pesaing Indonesia diantaranya Malaysia dan Thailand. Dengan kekayaan ikan hias yang berlimpah, maka peluang Indonesia sebagai pengekspor komoditas ini sangat besar. Ikan hias air tawar yang dibudidayakan di Indonesia diharapkan dapat menjadi komoditas unggulan antara lain discus, botia, rainbow, arwana dan corydoras (Lesmana dan Dermawan, 2002).

Keindahan warna dan bentuk tubuh arwana sangat mengagumkan. Karenanya ikan yang dianggap sebagai pembawa hoki ini banyak dicari para pecinta ikan hias di dalam maupun di luar negeri. Permintaan ikan arwana terutama oleh masyarakat luar negeri setiap tahun terus meningkat. Tingginya permintaan dari negara-negara pengimpor belum mampu dipenuhi oleh produsen ikan arwana (penangkar) dalam negeri (Momon dan Hartono, 2002). Maka dari itu diperlukan adanya informasi tentang pemijahan ikan Arwana. Tujuan praktek kerja lapang yang telah dilakukan untuk mengetahui standard operasional yang benar tentang pemijahan alami ikan arwana super red di PT. Arwana, dengan mengetahui standard operasional teknik pemijahan ikan arwana dapat ditemukan juga hambatan yang muncul saat proses pemijahan ikan arwana super red.

\section{METODOLOGI \\ Waktu dan Tempat}

Praktek kerja lapang ini telah dilaksanakan di PT. Arwana Indonesia yang terletak di Pondok Ranggon, Harja Mukti, Kecamatan Cimanggis, Kabupaten Depok, Provinsi Jawa Barat. Kegiatan ini akan di laksanakan pada 12 Januari - 20 Februari 2013.

\section{Metode Penelitian}

Metode yang digunakan dalam Praktek Kerja Lapang ini adalah metode deskriptif, yaitu metode yang menggambarkan kejadian atau keadaan pada daerah tertentu. Menurut Suryabrata (1993) metode deskriptif adalah suatu metode yang bertujuan untuk memberikan gambaran umum, sistematis, faktual dan valid mengenai data-data yang berupa fakta-fakta dan sifat populasi tertentu dari suatu kegiatan. Pada umumnya penelitian deskriptif menggambarkan keadaan wilayah tertentu tanpa memberi analisis data yang terkumpul (Samhudi, 1985).

\section{HASIL DAN PEMBAHASAN Persiapan kolam}

Kolam ikan arwana yang baik memiliki jenis tanah berlempung dan derajat kemiringan saluran pemasukan dan pengeluaran maksimal satu persen serta berukuran 10x10 $\mathrm{m}^{2}$ (Wibawa, 2013). Kolam indukan dan pembesaran ikan arwana super red yang digunakan di PT. Arwana Indonesia memiliki kriteria yang hampir sama yaitu berupa kolam tanah dengan dinding pembatas terpal dengan kemiringan $75^{\circ}$ serta luas $(60 \times 28 \times 2) \mathrm{m}^{3}$ dan $(35 \times 30 \times 2) \mathrm{m}^{3}$.

Kolam terlebih dahulu dilakukan pengeringan air dengan menggunakan pompa diesel berkapasitas 15,5 HP, dan dilakukan pembersihan dari rumput dan ganggang. Lumpur juga dibersihkan menggunakan bambu yang dimodifikasi menjadi alat untuk penyeka rumput. Pengeringan kolam dilakukan di bawah terik matahari selama dua hari hingga tanah benar-benar tidak mengandung air, selanjutnya dilakukan pengisian air hingga ketinggian 1,5 meter dan dibiarkan selama tiga hari sebelum dilakukan penebaran induk.

\section{Kualitas Air}

Parameter kualitas air untuk ikan arwana sangat diperhatikan terutama suhu dan $\mathrm{pH}$ di dalam kolam. Suhu yang terdapat di kolam PT. Arwana sekitar 27$29^{\circ} \mathrm{C}$ dan $\mathrm{pH}$ berkisar antara 6,5 - 7,5. Menurut Ramadlon (2011), kualitas air dijaga agar mendekati lingkungan alami arwana yaitu $\mathrm{pH}$ 6,8-7,5 dan suhu 27$29^{\circ} \mathrm{C}$. Penggantian air dilakukan sebanyak $30-34 \%$ dari total volume dengan air deklorinisasi. 


\section{Seleksi Induk}

Penyeleksian induk untuk ikan arwana harus benar-benar diperhatikan ras murni, bentuk morfologi, umur induk, berat badan serta kesehatannya. Penyeleksian induk juga dapat dilihat dari tingkat kematangan gonadnya. Ciri-ciri induk betina yang matang gonad yaitu perut mulai turun, pada usus menjadi lebar dan warnanya cerah pada saat di kolam, jika dilihat dari perilaku induk betina yaitu kepala betina menghadap ke atas (menganga) sedangkan pada induk jantan yang matang gonad yaitu nafsu makan berkurang bahkan tidak mau makan dan warna tubuhnya lebih cerah dari biasanya. Apin (2005) menyebutkan indukan yang berkualitas diindentifikasi berdasarkan ciri fisik dan non fisik. Ciri fisik secara garis besar berdasarkan 2 bagian yaitu kepala dan tubuh.

\section{Pemberian Pakan}

Pakan yang digunakan di PT. Arwana Indonesia dalam pemijahan terdapat empat jenis yaitu jangkrik, ulat jerman, udang beku yang sudah dikuliti (skinless) dan katak dalam kondisi hidup, seperti yang dikatakan Ramadlon (2011) pakan hidup merupakan jenis pakan utama bagi arwana sebagai ikan karnivora. Pakan yang diberikan pada ikan budidaya hendaknya bervariasi untuk menekan resiko kekurangan gizi tertentu. Pemberian pakan yang dilakukan di PT. Arwana Indonesia menggunakan tipe pemberian pakan hingga ikan tidak makan lagi (ad libitum), hal ini dilakukan pada sore hari yakni pukul 16.00.

\section{Proses Pemijahan Alami}

Teknik pemijahan ikan yang dilakukan di PT. Arwana adalah teknik pemijahan secara alami dengan kondisi kolam yang dibuat serupa dengan habitat aslinya. Ikan arwana yang akan memijah dapat dilihat dari cara berenang yang berpasangan dan memisahkan diri dari kelompok, biasanya ditunjukkan dengan ciri-ciri berenang di pinggir kolam.
Pasangan yang telah berenang berduaan akan saling menjaga. Induk yang sudah berpasangan akan melawan jika ada induk lain yang mengganggu/mendekat. Proses pemijahan tidak berlangsung begitu saja, daya rangsang luar seperti curah hujan, suhu, dan kondisi air akan mempengaruhi rangsangan induk betina untuk melepas telur. Suhu yang optimal untuk arwana memijah adalah $27^{\circ} \mathrm{C}$.

Pemijahan ikan arwana berlangsung secara external fertilization atau pembuahan di luar tubuh. Induk betina akan mengeluarkan telur dan kemudian induk jantan mengeluarkan spermanya untuk membuahi telur. Telur hasil pembuahan akan disimpan oleh induk jantan di dalam mulut selama dua bulan, dalam jangka waktu itu induk jantan tidak akan makan atau berpuasa. Ukuran mulut induk jantan menjadi lebih besar dan rahang bawah menggelembung. Telur yang di dalam mulut induk jantan akan disimpan hingga menetas menjadi larva. Menurut Keppri (2011), setelah mampu berenang pada umur sekitar 2 minggu, larva dimuntahkan keluar dari mulut si jantan. Jika ini dibiarkan larva yang baru menetas tersebut dapat dimakan kembali oleh si induk atau di mangsa arwana lain. Karena itu larva perlu dipanen paksa sebelum masa pengeraman berakhir.

\section{Pemanenan}

Induk yang mengerami telur dijaring kemudian dipilih oleh manajer operasional yaitu Bapak Suwandi. Cara mengeluarkan telur dari mulut, ikan harus berada di dalam air. Ikan terlebih dahulu diputar supaya kondisi ikan tenang, salah satu mata ikan harus ditutup dengan kain. Mulut ikan harus dibuka lebar supaya telur yang ada didalam keluar tanpa terkena bibir dan gigi ikan dan hanya boleh dilakukan satu kali pengeluaran, supaya telur tidak mengalami kerusakan. Dari data yang diperoleh di PT. Arwana Indonesia, hasil panen yang di dapat pada siklus ini sebanyak 40 ekor. 
Selama PKL panen dilakukan sebanyak satu kali dengan perhitungan HR sebagai berikut:

$$
\begin{aligned}
\text { Hatching rate }(\mathrm{HR})_{\text {rata-rata }} & =\frac{\text { Jumlah telur menetas }}{\text { Jumlah telur dibuahi }} \times 100 \% \\
\text { Hatching rate }(\mathrm{HR})_{\text {rata-rata }} & =\frac{40 \text { ekor }}{40 \text { butir }} \times 100 \% \\
& =100 \%
\end{aligned}
$$

\section{Hama dan Penyakit}

Pada saat Praktek Kerja Lapang di PT. Arwana Indonesia ditemukan hama jamur putih yang mengakibatkan keroposnya sirip ikan arwana. Menurut Apin (2005) salah satu penyakit infeksius yang menyerang Ikan Arwana Silver adalah jamur Saprolegnia sp. Penyakit ini dapat menyebabkan luka pada kulit, otot daging hingga ketulang. Jamur putih tidak hanya berpredileksi pada sirip melainkan tubuh ikan. Ikan yang terlambat ditangani akan mengalami kematian, karena infeksinya akan menyebar sampai ke jaringan tubuh lainnya yang berakibat ganggungan pernafasan.

Cara pengobatan jamur putih yaitu dengan melakukan karantina ikan pada akuarium yang telah diberi tetracycline (4,5 gram) dan alat peningkat suhu selama tujuh hari berturut-turut. Metode ini dilakukan supaya jamur yang menginfeksi cepat mengalami pengeringan atau mati.

\section{KESIMPULAN DAN SARAN Kesimpulan}

Kesimpulan yang dapat ditarik dari praktek kerja lapang di PT. Arwana Indonesia yaitu teknik pemijahan alami ikan arwana adalah proses melepaskan telur dan sperma untuk pembuahan. Teknik pemijahan alami dimulai dari persiapan wadah untuk seleksi induk, proses pemijahan, panen dan pemeliharaan larva ikan arwana super red. Seluruh kegiatan harus memperhatikan kondisi lingkungan yang menyerupai habitat asli, manajemen pakan dan menjaga kondisi kualitas air sangat penting mendukung suksesnya pemijahan. Hambatan pada proses pemijahan ikan arwana super red ini terdapat pada sumber pakan pada pemeliharaan induk.

\section{Saran}

Ketersediaan pakan sebaiknya selalu dikontrol karena sering kali kosong dan menyebabkan induk tidak diberi makan sampai stok kembali ada.

\section{DAFTAR PUSTAKA}

Apin. 2005. Memilih Anakan dan Meningkatkan Kualitas Arwana. Agromedia Pustaka. Tangerang. 84 hal.

Kepala Pusat Penyuluhan Kelautan dan Perikanan, 2011. Budidaya Ikan Arwana.

Lesmana, D.S dan I. Darmawan. 2002. Budidaya Ikan Hias Air Tawar. Penebar Swadaya. Jakarta. Hal. 152-155

Momon dan Hartono, 2002. Pembenihan Arwana. Penebar Swadaya. Jakarta.

Murtidjo, B. A. 2005. Penangkaran Ikan Arwana. Kanisius. Yogyakarta.

Ramadlon, Maulana Jaya. 2011. Ternak Ikan Arwana. Yogyakarta. 5 Hal.

Susanto, heru. 2001. Arwana. Penebar swadaya. Jakarta.

Susanto, H. 2008. Panduan Memelihara Arwana. Penebar Swadaya. Jakarta.

Wibawa, S. 2013. Panduan Memelihara dan Merawat Arwana. Terra Media. Yogyakarta. 